Criminal Defence in China: The Possible Impact of the 1996 Criminal Procedural

Law Reform

\author{
H. L. Fu
}

The China Quarterly, No. 153. (Mar., 1998), pp. 31-48.

Stable URL:

http://links.jstor.org/sici?sici=0305-7410\%28199803\%290\%3A153\%3C31\%3ACDICTP\%3E2.0.CO\%3B2-0

The China Quarterly is currently published by School of Oriental and African Studies.

Your use of the JSTOR archive indicates your acceptance of JSTOR's Terms and Conditions of Use, available at http://www.jstor.org/about/terms.html. JSTOR's Terms and Conditions of Use provides, in part, that unless you have obtained prior permission, you may not download an entire issue of a journal or multiple copies of articles, and you may use content in the JSTOR archive only for your personal, non-commercial use.

Please contact the publisher regarding any further use of this work. Publisher contact information may be obtained at http://www.jstor.org/journals/soas.html.

Each copy of any part of a JSTOR transmission must contain the same copyright notice that appears on the screen or printed page of such transmission.

JSTOR is an independent not-for-profit organization dedicated to and preserving a digital archive of scholarly journals. For more information regarding JSTOR, please contact support@jstor.org. 


\title{
Criminal Defence in China: The Possible Impact of the 1996 Criminal Procedural Law Reform*
}

\author{
H. L. Fu
}

Criminal procedure in China had been governed by the 1979 Criminal Procedure Law (CPL 1979). ${ }^{1}$ This was amended in 1996 (the Amendment). ${ }^{2}$ In many aspects, the Amendment introduces important changes to the previous procedures and significantly redistributes the existing division of powers within the criminal justice system. It restricts police power and the prosecution's discretion. It enhances the position of the court and differentiates the role of judges. ${ }^{3}$ It also offers more protection for the rights of the accused and enhances the position of defence lawyers in the criminal process in substantive and procedural aspects. Consequently criminal lawyers are expected to play a more active and meaningful role in criminal defence.

Justice demands that individuals accused of criminal activity have the right to defend themselves before the law, and this principle is contained in the Chinese Constitution 1982, which states that "the accused has the right to defence." 4 This principle is also provided in Article 26 of the CPL 1979. Although the accused may invoke the constitutional right to counsel, this right had been substantially limited and grossly distorted by subordinate laws, government regulations and administrative discretion. According to Zhang Sihan ${ }^{5}$ from the Supreme People's Court, on average, only 20 to 30 per cent of defendants have been represented by lawyers during the trial; even in cases of serious criminal offences, only 40 per cent of defendants retained lawyers. Furthermore, the CPL 1979 structured China's criminal process in such a way that, in law and in

\footnotetext{
* An earlier version of this article was read at the Conference on Market Economy and Law in China, City University of Hong Kong, October 1995, and the Conference on the Right to Fair Trial, Hong Kong University, November 1996. The author would like to thank Dr Richard Cullen for his suggestions and helpful comments on the initial draft.

1. For studies of the CPL 1979 in English language, see Albert H. Y. Chen, An Introduction to the Legal System of the People's Republic of China (Singapore: Butterworths, 1992), ch. 9; Lawyers Committee for Human Rights, Criminal Justice with Chinese Characteristics (New York: Lawyers Committee for Human Rights, 1993); Shao-chuan Leng and Hungdah Chiu, Criminal Justice in Post-Mao China: Analysis and Documents (Albany: State University of New York Press, 1985).

2. The new law became effective on 1 January 1997. For commentaries on the Amendment, see H. L. Fu "Criminal Procedure Law," in Wang Chengguan and Zhang Xianchu (eds.), Introduction to Chinese Law (Hong Kong: Sweet \& Maxwell Asia, 1997); and Lawyers Committee for Human Rights, Opening to Reform? An Analysis of China's Revised Criminal Procedure Law (New York: Lawyers Committee for Human Rights, 1996).

3. Art. 12 of the Amendment expressly states that: "No one is guilty of a crime without a people's court rendering a judgment according to law."

4. Art. 125, Constitution of the People's Republic of China.

5. Zhang Sihan, "Several proposals on the reform of the model of trial," Zhongguo faxue (Chinese Legal Studies), No. 5 (1994), p. 47.
}

(C) The China Quarterly, 1998 
practice, a criminal trial and the role of defence attorneys were mere formalities.

Will the 1996 Amendment make any practical difference in improving the accused's right to counsel? The Lawyers Committee for Human Rights cautions that: "Since the revisions are intended to change ingrained patterns of behaviour by law enforcement officials, it seems likely that the gap between the law and the practice of criminal justice in China will actually grow wider, at least in the short term." ${ }^{6}$ But, on the other hand, without the Amendment itself, no change at all is likely. This article examines the fundamental flaws in the criminal defence provided in the CPL 1979, and discusses how criminal defence may be improved under the Amendment and what the limitations are in protecting the rights of the accused.

\section{The Role of Defence Lawyers under the CPL 1979}

Once the procuratorate initiated proceedings against an accused and transferred the case to court, the court formed a collegial panel, composed of judges and people's assessors, to try the case. ${ }^{7}$ Before the trial, the panel held meetings to discuss the case and to make a decision on the nature of the offence as well as on the sentence. In serious cases, decisions were made by the Judicial Committee, which was the leading body of any court. ${ }^{8}$ Where a case was complicated or important, the opinion of the superior court or even the Supreme People's Court might also be sought. It was normal practice in China that a case was decided before a trial and that those who tried the case might not have the power to make the decision.

The court had to try the case unless there was not "clear and sufficient evidence" to support the prosecution, in which event the court would remand the case to the procuratorate for supplementary investigation. The court might ask the prosecution to withdraw its case if no criminal punishment was necessary. ${ }^{9}$ When clarification was necessary, a people's court might initiate its own inquests, examination, search, seizure and expert evaluation. The fundamental characteristic of Chinese criminal trials under the CPL 1979 was that, through the pre-trial investigation, the judges decided on the facts and on the law involved. As a matter of law, no court would open a court session if the collegial panel was not certain about the facts, the offence and the sentence. ${ }^{10}$

6. Lawyers Committee for Human Rights, Opening to Reform? p. 1.

7. Except for "minor criminal cases and cases otherwise provided for by law" which can be tried by a single judge. Article 10, Organic Law of People's Court 1983 (OLPC).

8. Art. 11 of the OLPC states that the members of the judicial committee are appointed and removed by the Standing Committee of the People's Congresses at the corresponding levels, upon the recommendation of the presidents of these courts. The task of the judicial committee is to "practise democratic centralism," including summing up judicial experience and discussing important or difficult cases. As a practice, a judicial committee includes the president of a court, the vice-presidents and judges in charge of the different divisions (criminal law, administrative law, etc.).

9. Art. 108, CPL 1979.

10. Art. 109. 
Judges' involvement in the pre-trial investigation seriously diminished the role of defence lawyers. The trial judges would necessarily have prejudiced views on the case after they had read through the files and verified the evidence. They had difficulty in accepting alternative views from the parties, especially the defence. A challenge to the charge was not so much a challenge to the prosecution's case as a direct attack on the court's credibility. Unless there was strong new evidence, an open trial could not render any assistance to a defendant. ${ }^{11}$

Political interference in criminal defence was certainly the most serious problem facing any attempt to reform the system. When criminal defence was re-introduced into China's criminal justice system in the early $1980 \mathrm{~s},{ }^{12}$ the reaction from many governmental departments, including the courts, was hostile. In 1981, there were reports that court regarded defence lawyers as "troublemakers," "burdens" and "hindrances," the procuratorate called them "experts in picking bones from eggs" who would use loopholes to destroy the prosecution's case. ${ }^{13}$ Defence lawyers complained that the "lawyers' function is not correctly understood and otherwise lawful defences are blatantly interfered with and limited."14

The most blatant interference took place in 1983 when the government launched its campaign on crime in China. The Ministry of Justice issued a Notice which severely limited the right of the defence and eventually made the defence part of the prosecution team. ${ }^{15}$

This Notice required that once the court appointed a defence lawyer to defend an accused, the lawyer was obliged to accept the task. Where there were no defence lawyers, Party and government officers could be seconded temporarily to serve the purpose. Defence lawyers were told that they should not direct their minds to "trivial matters and technicalities" where the main facts were clear; they should not even raise the issue of

11. In rare cases, a lawyer may be able to persuade the court to change its pre-determined verdict. In a recent trial, a trial court was persuaded to accept a not guilty defence after "repeated studies and with permission." It is important to note that the defence lawyer in that case is a well-known criminal law professor and his personal influence had an effect. Zhao Binzhi, "Correctly distinguish a violation of financial disciplines and the offence of embezzlement," Zhongguo lüshi (China Lawyer), No. 3 (1995), p. 5 (interview with Professor Zhao Binzhi, July 1995). It is openly conceded by judges and lawyers interviewed by the author that a "well connected" lawyer will be useful for an accused. This article is partially based upon the author's informal and open-ended interviews with five judges, three prosecutors and 11 defence lawyers since 1995.

12. The system of criminal defence was formally set up in the People's Republic of China in January 1956. The system was met with hostility and abolished in late 1957. See Xu Jincun, Lüshi xue (Studies on Lawyers) (Chengdu: Sichuan People's Press, 1994).

13. Zhao Ying, "The position of defence lawyers in criminal litigation," in Ministry of Justice (ed.), Zhongguo sifa xingzheng de lilun yu shijian (Theory and Practice of Judicial Administration in China) (Beijing: Ministry of Justice, 1992), p. 1361. This book includes the abridged version of more than 1,000 published articles and conference papers related to the work of the Miristry.

14. Jiang Daijing "Protecting lawyers' rights in criminal litigation," in Ministry of Justice, Theory and Practice, p. 1367.

15. Ministry of Justice, "Notice on making full use of lawyers in severely striking down on crimes (14 October 1983)," Zhonghua renmin gongheguo falü guifanxing jieshi jicheng (Compilation of Normative Interpretations of Law of the People's Republic of China) (Changchun: Jilin People's Press, 1990), pp. 1730-31 (hereinafter Compilation of Normative Interpretations). 
mitigation if there were not apparent mitigating factors. Furthermore, if defence lawyers found that the main facts of the case were not clear or the application of law was mistaken, they should communicate this to the court or procuratorate before a trial. In cases in which the death penalty could be imposed, defence lawyers should first convey their objections, if any, to the local Party committee via the local Bureau of Justice. $^{16}$

Even though the Notice was issued specifically to serve the 1983 nation-wide war on crime, it continued to have an impact. Jiang ${ }^{17}$ commented on incidents involving interference with lawyers' work and harassment of defence lawyers:

A few cadres blame defence attorneys for ignoring the larger social interests and blindly following the law during a trial; some departments in charge of lawyers even impose numerous restrictions on the defence. They may forbid lawyers to conduct a serious defence, they may even disallow a not guilty plea. In extreme cases, they even treat lawyers as co-conspirators of the defendants because of their defence, and the lawyers' liberty cannot be protected.

For some firms, a reporting system was created to ensure political control over the work of criminal defence. In Nanjing city, for example, "collective decision making is required in serious and complicated cases; for cases where a not guilty plea is proposed or no consensus can be reached in the firm, they will be referred to the Bureau of Justice for a decision." $" 18$

There has been less political interference in lawyers' defence work in criminal trials during the $1990 \mathrm{~s}$. The legal profession in general is gradually becoming more independent, essentially a private business which cannot be tightly controlled by the government. ${ }^{19}$ One indication of such a development is the frequent use of a not guilty plea. In sensitive cases, such as that of $\mathrm{Xi}$ Yang, a Hong Kong-based reporter accused of unlawful disclosure of state secrets, ${ }^{20}$ and those against Wang Dan, Wei Jingsheng and other dissidents for sedition and subversion, ${ }^{21}$ not guilty pleas were seriously argued by the defence. The court, on the other hand, is often unsatisfied by the prosecution's case and, although this happens rarely, may give a not guilty verdict to assert its independence.

16. Ibid.

17. Jiang Daijing, "Protecting lawyers' rights."

18. Tan Zhen, "On pre-trial communication," in Ministry of Justice, Theory and Practice, p. 1380.

19. Zhen Dong, "Lawyers no longer officials," China Law, No. 1 (1994), p. 30.

20. See H. L. Fu and Richard Cullen, Media Law in the PRC (Hong Kong: Asia Law and Practice, 1996), ch. 6. Carlos Wing-Hung Lo, "Criminal justice reform in post-crisis China: a human rights perspective," Hong Kong Law Journal, No. 27 (1997), p. 90.

21. Ibid. H. L. Fu, "Sedition and political dissidence: towards legitimate dissidence in China?" Hong Kong Law Journal, No. 26 (1996), p. 210; Human Rights Watch, Slamming the Door On Dissent: Wang Dan's Trial (New York: Human Rights Watch, 1996). 


\section{A Defendant's Right to Counsel}

\section{Article 110 of the CPL 1979 states:}

After a people's court has decided to open a court session, it shall proceed with the following work: ... (2) to deliver to the defendant a copy of the bill of prosecution of the people's procuratorate no later than seven days before the opening of the court session and inform the defendant that he may appoint a defender or, when necessary, designate a defender for himself.

This seven-day rule effectively prevented any involvement by a defence lawyer at the investigation and prosecution stages of a criminal case. In other words, a defence lawyer had no right in law to enter the police station and the procurator's office to obtain information or meet and correspond with the accused. Practically, no legal representation was allowed until a week before the trial. ${ }^{22}$

In the vast majority of cases there were only one or two days available for a lawyer to prepare a defence. In a complicated case there might be hundreds of pages of documents and it would be impossible for a lawyer to review all the main facts. ${ }^{23}$ The defence lawyer for a dissident after the 1989 "Tiananmen incident" was only given four days to examine a thousand pages of documents filed by the prosecution. ${ }^{24}$ In 30 per cent of instances, cases were already at trial when the lawyer received the notice. ${ }^{25}$ Without legal representation during the investigation and prosecution stages, the police and procurators might, as happened frequently, force or falsify confessions, or record only those statements favourable to the prosecution's case. ${ }^{26}$

The lack of time to prepare a defence had been recognized officially. A Joint Notice provided that where a case was complicated and time was not sufficient for preparing a defence, the defence lawyer might ask the court to delay the trial, and "the court should consider the application if the delay would not affect the trial of the case within the limit provided by law."27

22. Even this seven-day rule is violated by provincial legislation. In the Rules on Lawyers in Guangdong province and Anhui province, the notification period is shortened to three days. Art. 12, Several Provisions of Anhui Province on the Performance of Duties of Lawyers (1988); Art. 8, Several Provisions of Guangdong Province on the Performance of Duties of Lawyers (1987). Difangxing fagui xuanban (Selections of Local Regulations), p. 1651 and p. 2558 respectively.

23. Legislative Affairs Commission (LAC), National People's Congress Standing Committee, Submission of the Ministry of Justice on the Amendment of CPL 1996. The LAC held several consultation meetings with interested parties. The participants' submissions were summarized and distributed by the LAC. The nature of these documents is not clear. They are not publicized and their distribution is restricted to related government departments. But they are not formally classified as state secrets or internal materials. For a study of confidential information in China, see Fu and Cullen, Media Law, and Huai Yan and Suisheng Zhao, "Notes on China's confidential documents," The Journal of Contemporary China, No. 4 (1993), p. 75.

24. Lawyers Committee for Human Rights, Criminal Justice with Chinese Characteristics, p. 32.

25. LAC, Submission of the Ministry of Justice on the Amendment of CPL 1996.

26. LAC, Submission of Supreme People's Court on the Amendment of CPL 1996.

27. The Supreme People's Court, Supreme People's Procuratorate, Ministry of Public Security and Ministry of Justice, "Joint notice on several concrete provisions on lawyers' participation in litigation (27 April 1981)," in Compilation of Normative Interpretations, pp. 1727-28 (hereinafter Joint Notice). 
In practice, however, such extensions were rarely granted. ${ }^{28}$ Even this limited protection was later abolished for some offences. According to the 1983 Decisions of the Standing Committee of the National People's Congress, the seven-day time limit "may be overstepped" for defendants "who cause explosions or commit murder, rape, robbery or other crimes seriously endangering public security, and who are punishable by death, where the main facts of the crimes are clear, the evidence is conclusive and the popular indignation is exceedingly great." 29

In addition to the time constraints, defence lawyers' right of access to files and to the accused was limited. At the pre-trial stage, defence lawyers had the right to "consult the file record of the current case, acquaint themselves with the circumstances of the case, and meet and correspond with the defendant in custody." ${ }^{30}$ According to the Joint Notice, lawyers might review the files in court and the court had the duty to provide necessary assistance, such as providing a room and allowing lawyers to make extracts from the files.

However, there were two limitations on lawyers' review of court files. First, the minutes of the Judicial Committee and the collegial panel could not be reviewed. This was a serious limitation given the fact that the Judicial Committee and collegial panel normally made a determination as to the offence and punishment prior to a trial. A Supreme People's Court document even classifies these minutes as "state secrets." 31 Secondly, courts could not provide satisfactory facilities for the defence. One study ${ }^{32}$ of ten courts and seven law firms in China shed light on the reality of defence rights in reviewing court documents. Fang Deming investigated 22 criminal trials of the first instance, and found that lawyers did not have access to the full files in eight cases (36 per cent). Two sets of chairs and tables were provided in one court, but the other nine did not provide any facilities for lawyers to read and extract material from the files. The main problem, according to the author, was that most of the courts regarded legal representation as a mere formality. The common practice was that a defence lawyer would be given only what he specifically requested and any other documents would not be voluntarily offered by the court. Judges were especially reluctant to share evidence uncovered through their own investigation. They tended to produce that evidence only in court.

28. Zhou Guojun, "Discussion on the time when lawyers' intervention is allowed," Zhongguo lüshi (China Lawyer), (1994), p. 32.

29. National People's Congress Standing Committee, Decisions Regarding the Procedure for Prompt Adjudication of Cases Involving Criminals Who Seriously Endanger Public Order (1983).

30. Art. 29, CPL 1979.

31. Supreme People's Court and the State Administration of Protecting Secrets, Regulations on the State Secrets Involving the Work of the People's Courts and the Classification (1989). See Fu and Cullen, Media Law.

32. Fang Deming, "Defence lawyers' right and duty in reviewing files," in Ministry of Justice, Theory and Practice, p. 1365. 
Interviewing an accused in police custody was a difficult matter for lawyers. Police concern over security hindered frank communication between lawyers and their clients. ${ }^{33}$ The Joint Notice required a detention centre to provide necessary assistance for lawyers to interview their clients, including the provision of proper premises. It also asked the police to strike a balance between security and right to counsel. Though it did not require the guards to be absent during the interview, it required them to be wary that their presence did not make defendants afraid of talking to their defence attorneys. After the interview, the guards should not question defendants about the content of their interview. A similar requirement was made by the Ministry of Justice and the Ministry of Public Security in a 1956 Joint Notice. ${ }^{34}$

\section{Pre-trial Disclosure}

No exchange of information was required between the defence and the procuratorate at the pre-trial stage and the two sides made their first contact in the court room. According to the CPL 1979, the procuratorate had to deliver the files of a case, together with the evidence collected, to the court. The defence had the right to review these files and evidence. In many cases, the family members of the accused retained a lawyer immediately after the detention or arrest, and the lawyer conducted an informal investigation of the case, even though he did not have the right to do so in law. Such an informal investigation might produce new evidence which might not be known to the procuratorate and the court. The defence could use such evidence to launch a surprise attack on both the court and the prosecution's case at the trial. However, the defence might not want a showdown in a courtroom. If the lawyer disagreed with the procurator, it was usually better to convey his disagreement before the trial started, convincing the procuratorate and the court to change their minds and thus avoiding any serious conflict with the procurators and the judges.

An informal pre-trial conference procedure had developed in China to increase understanding among the parties. Initially used as a measure to expedite criminal trials during the campaign on crime in the early 1980 s, it received positive responses. ${ }^{35}$ First, it had been argued, especially by defence lawyers, that a pre-trial conference was useful in narrowing down the issues of the case, so that the parties could focus on differences during the trial stage. Secondly, defence lawyers were only provided a brief time in court to put forward their defence, and as a result their case might not be clearly understood or accepted by the court and procuratorate. If they

33. Lawyers Committee for Human Rights, Criminal Justice with Chinese Characteristics.

34. Ministry of Justice and Ministry of Public Security, "Joint notice on the problem of lawyers meeting the defendants in custody (13 November 1956)," in Compilation of Normative Interpretations, pp. 1748-49. The Notice required a detention station to provide a separate room, if possible, for a lawyer to interview his client, so that the defendant "would not feel worried."

35. Wu Jieming, "Preliminary discussion on pre-trial communication among lawyers, judges and procurators," in Ministry of Justice, Theory and Practice, p. 1376. 
could discuss with the judges and procurator beforehand, they had more time to explain their defence. This also allowed time for judges to digest the defence argument. ${ }^{36}$

Finally, and perhaps most importantly, court-room debate was a final showdown, a battle fought in public. A lawyer's defence was perceived to be a direct challenge to the authority of the court and the procuratorate. The court especially would not be ready to accept such an open challenge, even if they knew they were wrong. As one lawyer commented: "Sometimes a correct defence in court may put the procuratorate and court in an embarrassing position and thus damage their dignity." 37 Another lawyer from Jiangxi province suggested that: "Once a case is transferred to the court, the case would basically be decided. A public trial is a mere formality. It would be really difficult to ask the judicial organs to withdraw a wrong decision., ${ }^{38}$ Given the fact that a successful defence to a large extent depended upon the goodwill of the procuratorate and judges, it was essential to persuade the court to listen to the defence. A pre-trial meeting gave defence attorneys an opportunity to persuade the judges and procuratorate to alter their decision without embarrassing them in court. ${ }^{39}$

There had been strong objections to the pre-trial conference among Chinese lawyers. As a principle, it was said, defence lawyers should be independent from the court and procuratorate. If they had to share everything with the procurators, it would give the public an impression that the lawyers "wear the same pants and sing the same song." 40 The pre-trial conference had never become systematic and its existence always depended upon a lawyer's initiative. When properly conducted, it could compensate for a lawyers' disadvantages by providing an informal opportunity for them to communicate with the judges and procurators.

\section{The Rights of a Lawyer During the Trial}

The CPL 1979 set out a clear scenario of the manner in which the criminal trial should proceed. Throughout the trial, the judge was the dominant figure. The presiding judge opened the session by announcing the subject-matter of the case and introducing the participants. ${ }^{41}$ The public procurator then read out the Bill of Prosecution, which included the facts of the case, the law violated and the punishment sought. The

36. Ibid.

37. Ibid.

38. Zhang Zhanlin, "Lawyer's early involvement prevents a wrong conviction," Zhongguo lüshi (China Lawyer), No. 9 (1994), p. 6.

39. "A lawyer suspected that a defendant in a murder case was a psychiatric patient. He raised the defence of insanity in the pre-trial meeting, but was rejected by the judge. Then the lawyer invited experts to explain the case to the judges. After a pre-trial psychiatric examination participated in by the judge, procurator and lawyer, the procuratorate withdrew its charge." Zhao Zhongqing, "The necessity of exchanging information between lawyers and judicial personnel at pre-trial stage," in Ministry of Justice, Theory and Practice, p. 1376.

40. Guo Zhongwu, "The position of defence lawyers in criminal litigation," in Ministry of Justice, Theory and Practice, p. 1359.

41. Art. 113, CPL 1979. 
judges then started to question the defendant, and the public prosecutor might also question the defendant with the permission of the court. ${ }^{42}$ Next, the judges and prosecutors started to question witnesses, present the records of testimony of witnesses who were not present in court, and read out the conclusions of expert witness and documentary evidence. ${ }^{43}$

At this stage, the defence might raise questions. According to Article 115, CPL 1979: "The parties and the defenders may request the presiding judge to question the witnesses or expert witnesses, or ask the presiding judge's permission to put their own questions directly." But the court might stop the questioning of the defence if it considered it irrelevant.

During the trial, the defence might also call new witnesses and enter new evidence. But the court had discretion in granting such requests. ${ }^{44}$ For instance, they did not allow expert witnesses produced by the defence because there was no provision allowing such witnesses in the CPL $1979 .^{45}$

When the judicial inquisition was over, the procurator was allowed to make a speech to conclude his case; the accused was also allowed to make a statement. Afterwards, the defence was given an opportunity to make their case. A "debate" among the participants followed. When the judge regarded the issues of law and fact to have been fully debated, he might declare the conclusion of the debate and allow the defence to present a final statement. ${ }^{46}$

\section{The Dynamic of the Court Proceeding}

Given the fact that a case was decided before the trial, the trial could only be ritual, with the parties knowing that any input would be too little and too late. This was not to say that there was nothing a lawyer could say in court. There were occasionally tense debates, and sometime names were called and insults were exchanged between procurators and lawyers. As early as 1983, defence lawyers were criticized for using the court room as "a forum of free speech." 47

A major difficulty facing defence lawyers was that they could rarely question the prosecution witnesses and thus could only argue in the abstract. Defence lawyers were normally allowed to raise questions of any prosecution witness who testified, but the problem was that most of the witnesses did not testify in court but only provided a written statement which would be read out.

Another difficulty was that the court seldom treated the lawyers' arguments seriously. Most defence lawyers worked in state-owned firms

42. Art. 114.

43. Art. 116

44. Art. 117.

45. Yang Yinche, "Defence lawyers should have right to produce expert witness," Zhongguo lüshi (China Lawyer), No. 11 (1994), p. 8.

46. Art. 118, CPL 1979.

47. Xiao Shanren, "A person without legal qualification may not be a defender," in Ministry of Justice, Theory and Practice, p. 1319. 
as government employees. Compared with judges and procurators (also government employees but with higher administrative ranks), the status of lawyers was very low. Judges and procurators represented the state; lawyers were associated with "criminals." Lawyers were normally overwhelmed in court. ${ }^{48}$ Some judges openly discouraged defendants from hiring lawyers and some regarded using a lawyer as a waste of money "better to spend the money on some good meals." 49

The court treats lawyers' defence arguments as they please. They can simply disregard their opinions. You say whatever you prefer, I decide whatever I want ... Some judges openly ask the defendants: what is the use of hiring a lawyer? Don't waste your money. Some even claim that: "The punishment will be lenient without a lawyer, and will be severe with a lawyer." 50

The abuse of defence lawyers in criminal hearings was so prevalent that the Supreme People's Court, the Supreme people's procuratorate, the Ministry of Public Security and the Ministry of Justice found it necessary to issue a Supplementary Notice to address the problem. This stipulated that courts should respect a defence lawyer's basic rights:

- Courts should take defence arguments seriously. Written evidence provided by the defence and the statement of defence should be included in the court's files; other materials related to the case should also be included if necessary.

- Courts should consider the evidence presented by the defence. The court shall verify the evidence provided by the defence or ask the procuratorate to verify such evidence, so that it can be presented during the trial.

- Courts should not issue a summons to order a defence lawyer to defend an accused in court.

- Courts should pay due respect to defence lawyers in court and should not expel them from court rooms at will. ${ }^{51}$

\section{The Process of Reform}

The reform of China's criminal procedural law formally started in early 1995. There had been a consensus among the key players in the criminal justice system that defence lawyers should be available to an accused at an earlier stage. But opinions differed as to how early it should be, and, coloured by their different institutional interests, the police, procuratorate and court had different proposals.

48. Qiao Bin and Sun Qikang, "A preliminary study of the psychology of the criminal lawyers," in Ministry of Justice, Theory and Practice, p. 1404.

49. Tan Zhen, "On pre-trial communication," p. 1380.

50. Qiao Bin and Sun Qikang, "A preliminary study,"

51. Supreme People's Court, Supreme People's Procuratorate, Ministry of Public Security and Ministry of Justice, "Joint notice on several supplementary provisions on lawyers" participation in litigation (26 June 1986)," in Compilation of Normative Interpretations, p. 1736. 
The Supreme People's Court held the most liberal view, proposing that defence lawyers might intervene at the earliest stage of investigation. Through the early intervention of lawyers, any unlawful and deleterious activities of investigators would be brought to the court's attention. More importantly, the court's role in supervising the police and procuratorate would also be improved. The court's control had been limited mainly to the scrutiny of law and fact on the record prepared by the police and procurators. Most unlawful and prejudicial activities committed by the police and procuratorate did not appear on record and were not evident to the court. The early involvement of defence lawyers might protect the procedural rights of the accused. ${ }^{52}$

The Ministry of Justice, which regulates the legal profession in the country, held a similar view. Its officials proposed that whenever compulsory measures, such as detention and arrest, were imposed on a suspect, or whenever a suspect was summoned, he should be allowed to have legal representation. Earlier legal representation is the international standard which China should follow; and, through earlier involvement, defence lawyers could supervise the procedural fairness of the investigation. ${ }^{53}$

The Supreme People's Procuratorate agreed with earlier involvement of the defence at the prosecution stage in principle, but argued that the scope of such involvement should be different at different stages of an investigation. In addition, the right and duty of defence lawyers should be clearly stipulated. In particular, a defence lawyer's involvement should not be allowed to "interfere with the normal investigation." 54

The Ministry of Public Security strongly opposed defence lawyers' involvement in the investigation stage. It argued that this was a stage in which the police sought to clarify the facts of the case, to collect evidence and to prove crimes. The investigation would be hampered by defence lawyers. Thus before the police were clear about a case, there should be no legal representation. Furthermore, crime would continue to increase and become more complex in the future, it argued. Given that the police bore tremendous responsibilities in criminal investigation, involvement of defence lawyers at the investigation stage would be detrimental to police work. $^{55}$

While the key players in the criminal justice system were negotiating the redistribution of powers among themselves and making compromises on the rights of defendants and their legal representatives, the issue was also debated in public as part of the academic campaign for the reform of China's criminal process. There was a massive literature written by government officials and academics, published in law review journals, newspapers and magazines, largely supportive of liberalizing the criminal justice system and offering more protection of rights. ${ }^{56}$

52. LAC, Submission of Supreme People's Court on the Amendment of CPL 1996.

53. LAC, Submission of Ministry of Justice on the Amendment of CPL 1996.

54. LAC, Submission of Supreme People's Procuratorate on the Amendment of CPL 1996.

55. LAC, Submission of Ministry of Public Security on the Amendment of CPL 1996.

56. Lawyers Committee for Human Rights, Opening to Reform? 
It was openly admitted by an official from the Ministry of Justice ${ }^{57}$ that criminal defence under the CPL 1979 was "inconsistent with Article 125 of the Constitution." Many looked at criminal defence in common law jurisdictions to study how the rights of an accused could be better protected. In a draft CPL prepared by a law school in Beijing at the invitation of the National People's Congress, it was proposed that, where a suspect is detained or arrested, he should be allowed to contact a lawyer immediately or within 48 hours after his detention or arrest. ${ }^{58}$

Attempts to make lawyers accessible during the investigation stage were also made in some local jurisdictions. In the draft Lawyers Regulations in the Shenzhen Special Economic Zone, for instance, it was provided that in criminal cases, lawyers "may be entrusted to provide legal services for citizens or suspects on whom are imposed compulsory measures by the public security organs or the procuratorate, or who are summoned by the public security organs or procuratorate for the first time." 59 But when the draft regulations were passed by the local legislature, these provisions were deleted. ${ }^{60}$

It was commonly held by academics and many decision makers in China that increasing the role of lawyers would not be sufficient to protect the rights of defendants unless the procedure of the criminal trial was changed. It was pointed out that the pro-active role of the judge and the inquisitorial style of trial were sources of real difficulty. The thrust of the criticism was that when trial judges became investigators, they could not be fair and neutral in conducting the trial. It was argued that the inquisitorial system was no longer suitable in China and that a more adversarial system needed to be put in place. The Supreme People's Court supported this notion and proposed that while the presiding judge would continue to play the leading role in criminal trials, the evidence should be produced directly by prosecution and defence. More importantly, witnesses must testify in court and may be cross-examined.

According to the Supreme People's Court, a more adversarial system would have three advantages. ${ }^{61}$ First, the procurator and defence lawyer would be more responsible when each was made to bear the burden of presenting evidence. There had been mounting complaints about the deterioration in the quality of criminal trials in China and a more adversarial model was expected to improve the situation. Secondly, judges would not pre-determine a case and would become neutral adjudicators. A more adversarial system would rectify the phenomenon of

57. Zhang Wei, "Several questions in lawyers' participation in criminal litigation," Zhongguo faxue (Chinese Legal Studies), No. 5 (1994), p. 40.

58. Li Baoyue, "On the question of lawyers' participation in criminal litigation," Zhengfa luntan (Forum of Politics and Law), No. 4 (1994), p. 72; and Li Baoyue, "On the time when lawyers can participate in criminal litigation," Zhongguo faxue (Chinese Legal Studies), No. 4 (1994), p. 98.

59. Art. 26, Lawyers' Regulations of Shenzhen Special Economic Region (draft). On file with the author.

60. Shenzhen Special Economic Zone, Lawyers' Regulations of Shenzhen Special Economic Zone (1995). On file with the author.

61. LAC, Submission of Supreme People's Court on the Amendment of CPL 1996. 
"convicting before a trial." Thirdly, evidence, when it was presented by the witness directly in court, could be verified according to law.

The main objection to the proposal came from the Supreme People's Procuratorate which insisted that, although there were some problems in criminal trials, the present system was satisfactory. China should find its own way to reform trial procedures, instead of blindly following the "Western style." ${ }^{2}$ The procuratorate objected to reform mainly from a fear that a more adversarial system would diminish its status. Under the CPL 1979 , the procuratorate played the double role of prosecuting a criminal offence and supervising the court during the trial. ${ }^{63}$ Under the proposal, the role of supervision would be substantially diminished, if not abolished. Under a more adversarial system, the prosecution would be a party on the same footing, legally, as the defence, arguing a case to the court. ${ }^{64}$

The procuratorate's objections were shared by others. Many judges expressed their concern that a more adversarial system meant that all the witnesses would have to testify in court, a goal which could not be easily achieved in China. The current arrangement, where the majority of witnesses did not testify in court but presented a written statement, was difficult as many of the witnesses simply refused to sign their names on the statement. To demand that witnesses testify in an open court would further aggravate the problems. The lack of civic consciousness, hostility towards and fear of testifying in court and the financial burden of a prolonged trial all meant that a more adversarial system would face tremendous practical difficulties in implementation. ${ }^{65}$

\section{Legal Representation under the 1996 Amendment}

The 1996 Amendment enhances the position of the court in criminal proceedings and thus allows the defence counsel to play a more active and meaningful role. The prosecution bears the burden of proof. Where it decides to institute a prosecution, it will no longer transfer the evidence with the files to the court. The court will try a case where there is Bill of Prosecution which includes the alleged criminal facts, and has attached a list of evidence, names of witnesses and photocopies or photographs of primary evidence. ${ }^{66}$

The courts will no longer conduct or participate in any pre-trial investigation. In the Amendment, two important articles from the CPL

62. Lu Fei, "Reforming the model of trials," Zhongguo faxue (Chinese Legal Studies), No. 5 (1994), p. 48.

63. Art. 15 of the Organic Law of People's Procuratorate (1983) provides: "In legal proceedings instituted by a people's procuratorate, the chief procurator or a procurator shall attend the court session, in the capacity of state prosecutor, to support the prosecution and exercise supervision over the court proceedings, and to determine whether they conform to the law." According to Lu Fei (ibid.) from the Supreme People's Procuratorate, the procuratorate has the power to supervise the trial by raising objections whenever "there is something unlawful during the trial." But the objection raised is often ignored by the court. Judges in Zhuhai admit that the procuratorate's supervision is not very useful.

64. Lu Fei, "Reforming the model of trials," pp. 47-49.

65. LAC, Submission of Supreme People's Procuratorate on the Amendment of CPL 1996.

66. Art. 150, CPL 1996. 
1979 have been repealed: Article 108 which authorized a court to remand a case to the procuratorate for supplementary investigation, and Article 109 which authorized the court to conduct its own pre-trial fact-finding.

These changes shift the burden of leading evidence from the court to the procuratorate. Accordingly, the procuratorate alone will be responsible for the validity of the evidence, and the court will no longer examine the evidence prepared by the procuratorate before trial. If this procedural reform is faithfully executed, judges may become neutral arbitrators, who decide a case according to whatever evidence is given in court.

The Amendment increases the powers of the collegial panel. Article 149 states that a collegial panel has the right and duty to render its decision after trial. If the panel is unable to make a decision on a complex and important case after a trial, it should submit the case to the Judicial Committee for consideration and decision. ${ }^{67}$ There are two important changes. First, the collegial panel itself, not the President of the court, is to initiate the process of referring a case to the Judicial Committee for decision; secondly, such a referral occurs only after a trial is completed.

The reform of trial procedures will improve the quality of legal representation before and during a trial. Right to counsel is extended to the investigative stage. The Amendment divides legal representation in criminal procedure into two stages. At the investigative stage, an accused may retain a lawyer to provide legal consultancy. At the prosecution and trial stages, a defendant may retain a lawyer for criminal defence. A lawyer's rights differ at the two stages.

At the investigative stage, a lawyer has the right:

(1) to provide legal consultation, to represent the suspect or to lodge a complaint or accusation either from the first time a suspect is interrogated or from the day he is put under any restrictive measures by an investigative body; and

(2) to apply for bail on behalf of a suspect upon arrest. ${ }^{68}$

At the prosecution or trial stage, a lawyer has the right to read and copy case files, interview witnesses and the victim.

It is possible that a defence lawyer could make a difference in criminal trials in the future. The introduction of some adversary elements into criminal proceedings means, if anything, that the procurators have the burden of proving the guilt and leading evidence under a relatively neutral panel of judges. The defence should then have a real opportunity to challenge the prosecution's allegations.

\section{The Limits of the Law Reform}

The Amendment introduces elements of procedural justice into China's criminal justice system. There are high expectations that it will better protect the rights of a suspect. The substantial improvements in the law 
and the symbolic values embodied in it should provide an opportunity for such an improvement. But can the 1996 Amendment meet these expectations?

Some of the rights in the Amendment are qualified by other articles in it. Article 96 states that if a case involves state secrets, the suspect may not retain a lawyer without the permission of an investigative body, and where the lawyer is allowed, he may not meet or correspond with his client without further permission of the investigative body. In addition, investigators of a case may be present during the interview between a lawyer and his client "according to the circumstances of the case and necessity." ${ }^{\circ 9}$ While the Amendment clearly authorizes the lawyers to interfere at an earlier stage, it also equally explicitly authorizes the police to monitor and control the substance of the lawyers' service.

Article 38 is the most intimidating. It makes it a criminal offence for a defence lawyer to "help the suspect of a crime or defendant to conceal, destroy, or fabricate evidence; collude with each other; threaten or induce witnesses to alter their testimony, provide false evidence, or engage in other activities to interfere with the litigation procedure of the judicial organs." defined, the Article could have the chilling effect of stopping any assertive legal practice. In fact, many lawyers are saying that the Amendment as a whole may be a regression from the CPL 1979 in criminal defence. Until this Article is clarified, many lawyers would be reluctant to continue their criminal law practice for fear of prosecution. ${ }^{71}$

The promotion of rights in the Amendment may well have been incidental to the reform process. The Chinese criminal process relies upon the checks and balances among the three systems, each jealously guarding its power. Once one's power is in danger, such as when the police power of detention outside criminal procedures was challenged, it will directly challenge the others and aim to have the others' power adjusted, thus reaching a new balance. This domino effect creates room for rights to develop. The recognition of rights of an accused may well be incidental to the conflict, negotiation and compromise among the powerful institutes in China. The rights of defence lawyers are often swept aside as the Ministry of Justice has been in a weak position compared with the other players.

Some of the rights created in the Amendment are ambiguous, general and abstract. They cannot really be enforced. This makes them illusory and theoretical: a type of window dressing. They are not capable of having serious legal consequence. Although the Amendment may have recognized the presumption of innocence, for example, it provides no remedies on this principle. The court has no right to exclude evidence unlawfully obtained. Where an appellant finds that procedural justice has

69. Ibid.

70. Art. 38.

71. Interviews with lawyers from Beijing, January and February, 1997. See Lawyers Committee for Human Rights, Opening to Reform? p. 58. 
been grossly violated by a trial court, the only remedy available is to remand the case for a retrial. ${ }^{72}$ The court is not to quash a conviction simply because a court made a mistake, regardless of how serious it is.

While a defence lawyer may interview a client in police custody, the lawyer cannot obtain any assistance from the police except to be informed of "the name of the offence" the client is suspected to have committed. ${ }^{73}$ The prevailing cynical view is that the lawyer's earlier intervention is more superficial than substantial. In addition, while the lawyer's role may have been enhanced, real enhancement of defence possibilities is undermined by the absence of any improvement in legal aid. Without a strong commitment from the government to finance legal aid, most of the suspects will not benefit from the newly implemented legal rights. ${ }^{74}$

The abstract rights are subject to government interpretation. In Chinese practice, a law passed by the National People's Congress cannot operate by itself but has to be put into operation by implementation regulations passed by the executive government. The regulations can expand the government's power and limit rights of citizens. There are no principles that a law protecting rights has to be construed broadly and interpreted in favour of rights; that subsidiary legislation has to be consistent with parent legislation $^{75}$; or that national legislation cannot be inconsistent with the Constitution. All the rights are subject to redefinition and once the implementation regulations are passed, the rights may vanish or diminish.

The interpretation of "residential surveillance" in Wang Dan's case provides a good example. Police admitted they were holding Wang on 2 June 1995, but he was not indicted until 13 October 1996. It was not known when he was arrested and his family was not informed about it as they should have been under the CPL 1979. It appeared that the police detained Wang unlawfully but that such abuse (as prevalent as it was) would come to an end when the Amendment becomes effective. However, the police argued that the holding of Wang Dan was lawful because he was not detained at all. Instead he was put under residential surveillance.

72. A case shall be remanded for retrial in following circumstances: (1) the requirement for public trial is violated; (2) the requirement for withdrawal is violated; (3) the parties' lawful rights in litigation are deprived or unlawfully limited, and such deprivation and limitation may have prejudiced a fair trial; (4) the trial organs are not lawfully set up; or (5) there are violations of other rules regarding litigation procedures, and the violation may have affected a fair trial.

73. Art. 66, CPL 1996.

74. The Ministry of Justice is now formulating plans for legal aid in China. Pilot projects have been set up in Beijing and Guangdong. According to Shen Bailu, Head of the Department of Lawyers in the Ministry, China's legal aid will follow international experience and at the same time consider China's actual circumstances. The purpose of the proposed plan is to demonstrate the fairness and justice of the legal profession and force the legal profession to consider not only the economic effect of their profession but also the social impact. Thus the plan is both to serve those unable to afford lawyers and to enhance lawyers' public conscience and civic responsibility. Fazhi ribao, 22 February 1995.

75. For a study of the inconsistency between China's National Security Law and the Implementing Rules for the National Security Law, see H. L. Fu and Richard Cullen, "National security law in China," Columbia Journal of Transnational Law, No. 34 (1996), p. 149. 
This was a novel interpretation of the law, to say the least. As residential surveillance is retained in the Amendment it can be used by an investigative authority in the future, it seems, to hold a person in a unknown place for more than one year despite these recent changes in the law. ${ }^{76}$

The defendant's right to counsel, however it may have been enlarged by the 1996 Amendment, may be subjected to continued diminution in practice by the police. The Ministry of Public Security has proposed restrictions in its draft Implementation Rules so that a lawyer can only visit his client once during police investigation of a case for a limited period of time. ${ }^{77}$

Even if the government intends to implement the Amendment faithfully, there will be tremendous enforcement problems. The law is effective already, but so far the change is very slow, if there has been any at all. It will be enforced by the same police, procurators and judges. The Supreme People's Court and the Supreme People's Procuratorate have been circulating guidance to prepare for the enforcement of the new law. Yet they still disagree on several important issues, especially on the rules of evidence, which they have to develop from scratch.

Given the substantial changes made in the Amendment, one cannot help being cynical that the law in practice will definitely be different from the law in the book. How can it be possible for the police to accept genuine external review of arrest after near 50 years' practice of unsupervised arbitrary detention? How can a Chinese judge become accustomed to adversarial proceedings overnight after being an investigator/inquisitor throughout his career as a judge?

\section{Conclusion}

The key concept of the right to counsel is novel to Chinese legal culture. In the CPL 1979, there were few procedural requirements within the criminal process, and few protective measures to defend the rights of an accused. The CPL 1979 encouraged the police, the prosecutors and the judges to ascertain what they held to be the true facts of an offence with little regard to procedural rectitude. The rights of defendants were routinely ignored in the interests of crime control. The defendants and their defenders were marginalized within the criminal justice system. The constitutional right to counsel was severely restricted in form and substance.

The 1996 Amendment introduces an element of procedural justice into China's criminal justice system. There are high expectations that the

76. Zhang Waiguo, “The abuse of 'residential supervision' in Beijing," Mingbao, 31 October 1996. Such practices are said to be popular now. In the Shenzhen Special Economic Zone, for example, the police have built at least one hotel-style detention centre, where a suspect is detained for a prolonged period of time under the name of "residential surveillance." The suspect has to pay for the accommodation (interviews with lawyers from Shenzhen, May 1997).

77. Interview with three lawyers from Beijing, March 1997. They all predicted that the police proposal would meet strong resistance from the Chinese Bar. 
Amendment will better protect the rights of a suspect. The substantial improvement in the law and the symbolic values embodied in it are expected to provide an opportunity for such an improvement. However, given the ingrained pattern of practice in China's criminal justice system, the practical impact of the Amendment in protecting the right to counsel will be limited. Efforts to amend the law will not alone guarantee the protection of rights. Amending the CPL will not make the rights real unless they can be effectively enforced. While the Amendment may have laid a foundation for improvement, there is little likelihood that the legislation will bring about meaningful change in the practice of criminal defence in the near future. 